\title{
Does Leverage Always Mean Risk? Evidence from ASE
}

\author{
Zeyad S. Ramadan \\ Correspondence: Zeyad S. Ramadan, Professor of Finance, Finance and Banking Science Department, Applied \\ Science University. P.O. Box 166, Amman, Jordan. Tel: 962-796-943-000. E-mail: \\ ramadanzeyad39@yahoo.com
}

Received: September 21, 2012

Accepted: October 24, 2012 Online Published: November 5, 2012

doi:10.5539/ijef.v4n12p150

URL: http://dx.doi.org/10.5539/ijef.v4n12p150

\begin{abstract}
The aim of this study is to explore whether leverage always means risk. For this purpose, unbalanced pooled cross-sectional data regression of a sample of 30 Jordanian industrial firms listed in ASE in the years 2001-2011, and Beta coefficient $(\beta)$ as proxy for the systematic risk were utilized. Furthermore, four different definitions of the leverage have been tested to guarantee the credibility and generality of the results. Result show that leverage is a definite factor in estimating risk, and can explain $21 \%-24 \%$ of the variability in the systematic risk for the Jordanian industrial firms. Accordingly, the leverage from the Jordanian industrial firm's point of view always means risk, with the need to remember that risk is not necessarily a bad thing, since high profit potential often comes with high level of risk.

This result is consistent with the traditional theory of capital structure, where greater level of debt in the capital structure comes along with greater risk.
\end{abstract}

Keywords: leverage, systematic risk, Jordan

\section{Introduction}

There is no one formal definition for systematic risk, but generally speaking, systematic risk can be defined as the risk that affects the whole market or the whole market segment. Systematic risk is also known as un-diversifiable risk or market risk. Any action that cannot be avoided by diversification can be a potential source of systematic risk. It is well known that systematic risks cannot be escaped; it can only be hedged by adopting horizontal or vertical diversification.

The degree of risk a company may experience usually depends on several internal and external factors. Among other factors, external factors may include foreign investment policy, change in taxation clauses, shift in socio-economic parameters, and global security threat. The internal factors among other factors may also include size, complexity, business activities, investment policy changes, and financial leverage. Although all the above mentioned factors are important sources of systematic risk, this study emphasizes on financial leverage. In one hand, financial leverage gives the company many advantages to prosper by creating more investment opportunities and ultimately increases the shareholder value. One the other hand, it has many disadvantages. As the company uses financial leverage extensively, this may give the creditors feeling that the company is in a high risk. Consequently, this may increase the interest rate and may impose some borrowing restrictions on the company. Internally, this may affect the company's stock value if the stockholders start to doubt its financial status. This may result in a significant drop in the stock value of the company.

Great effort in literature has been directed toward exploring the relation between financial leverage and systematic risk. This study comes as one step forward to explore the question does leverage always mean risk? To answer this question, the yearly observations of a total of 259 industrial firms listed in Amman Stock Exchange (ASE) were analyzed.

\section{Literature Review}

One of the most important studies about the determinants of the systematic risks is that done by Beaver et al., (1970). Results illustrated that there is a significant correlation between Beta $(\beta)$ as a measure for systematic risks and all of financial leverage, Dividend structure, and Earnings yield. Hamada (1972), stated that the financial structure has a significant effect on systematic risks. 
A study conducted by Ross et al., (2001) showed that operational leverage and financial leverage are considered as determinants with a statistical significance for systematic risks. The study also showed that firms with high fixed costs compared to variable costs and whose revenues depend on business cycles fluctuations generally have high systematic risks percentages. Moreover, Hong and Sarkar, (2007), Kim et al., (2002), and Mnzava et al., (2009) have indicated that the debt ratio as a measure for financial leverage has a positive relation and a statistical significance with systematic leverage.

Shefrin and Statman, (2000) compared firms that have high debt ratios with firms that have low debt ratios from the difference in the systematic risks point of view. They figured out that $\beta$ is lower than that expected by the financial theories specially for those firm that increase their debt ratios relative to their previous state. Robert, (1979) in his study concluded that when the firms increase their debts without doing any changes on the equity, there may not be any effect on the systematic risks and systematic risks are a function of covariance between the expected return of the new investment after increasing the debt and the expected return of the market portfolio. In his study conducted on some Iranian companies, Kheder (2012) showed that operational leverage has no effect on Beta as a proxy for the systematic risks of the Iranian Companies.

\section{Data}

The financial data used in this study were obtained from Amman Stock Exchange (ASE). The reason for considering Amman Stock Exchange is that it is the only official financial market available in Jordan. All data along with their notations and methods of calculations are listed in Appendix (1).

\subsection{Risk Measurement}

One of the widely used methods for calculating the market risk is the market Beta $(\beta)$ of the Capital Assets Pricing model (CAPM). This which represents the balance in the trading off process between the expected return and the risk. Beta can be used to measure the sensitivity of the stock return relative to the market return such that if the value of Beta equals to 1, the change in the stock return relative to the change in the market return is 1:1 and the systematic risk for the stock, which cannot be avoided, equals to the systematic risk of the market as a whole. If Beta is less than one (beta can be seen as the slope of the stock return to market return), then the sensitivity of the stock return to change relative to the market return is less than one such that the change in the market portfolio return leads to less change in stock return and the systematic risk for this stock is lower than the systematic risk of the market portfolio. The investment in such a stock usually called "Defensive Investment". Having the slope of the line more than one, indicates that the change in market return leads to a bigger change in the stock return and the systematic risk for the stock is higher than the market risk. The investment in such a stock is usually called "Aggressive Investment".

It is worth to mention here that Beta represents the systematic risk for the stock that cannot be avoided by diversification. In this case, the CAPM suggests that the expected return for any financial asset has to equal the risk-free return rate plus the risk premium associated with the financial asset. Based on this, Beta is found from the CAPM model as:

$$
E\left(R_{i}\right)=R_{f}+\beta_{i}\left[E\left(R_{m}\right)-R_{f}\right]
$$

Where $E\left(R_{i}\right)$ is the expected rate of return on the financial assets $i, R_{f}$ is the risk-free rate of return, $E\left(R_{m}\right)$ is the expected rate of return of the market portfolio, and $\beta_{i}$ is the systematic risk for stock $i$.

In this study, $\beta$ is calculated individually for each of the study period and for each company covered in the study sample. This is done by using the daily returns of the company and the market as follows:

$$
\beta_{i}=\frac{\operatorname{Cov}\left(R_{i}, R_{m}\right)}{\operatorname{Var}\left(R_{m}\right)}
$$

where $\beta_{i}$ is the Beta for company $i$ which is used as a measure for systematic risk, $\operatorname{Cov}\left(R_{i}, R_{m}\right)$ is the covariance between the daily return for the asset $i\left(R_{i}\right)$ and the daily return for the market portfolio $\left(R_{m}\right)$, and $\operatorname{Var}\left(R_{m}\right)$ is the variance for $R_{m}$.

\subsection{Leverage Definitions}

Leverage generally refers to the financing methods of the company and its ability to meet the financial obligations. The Total Debt to Total Assets ratio (TDTA) is considered to be one of the most widely used ratio among the different leverage ratios used to measure the leverage of the company. TDTA includes all the financial sources, except the equity whether they are long or short term financial sources. 
To reach the goal of this study and to guarantee the credibility and the generality of its results, four different definitions explained below of leverage have been chosen.

\subsubsection{Total Debt to Total Assets (TDTA)}

This ratio is considered to be the most widely used ratio for leverage as it includes the short and long term debt and the tangible and intangible assets. It ratio indicates to what extent the company depends on outside financial sources to finance its assets. As this ratio increases, the financial risk increases for the company and the ability of the company to borrow decreases, the matter that will lead to a decrease in the financial elasticity of the company.

The TDTA can be calculated by adding both the long and the short term debt and dividing it by the total assets of the company, mathematically this can be written as follows:

$$
\text { Total Debt to Total Assets }=\frac{\text { Total Debt }}{\text { Total Assets }}
$$

Since the TDTA doesn't account for equity when calculating the obligations, TDTA can also be written as:

$$
\text { Total Debt to Total Assets }=\frac{\text { Total Assets }- \text { Total Shareholder's Equity }}{\text { Total Assets }}
$$

\subsubsection{Long Term Debt to Total Assets (LTDTA)}

This ratio indicates the extent to which the company uses its long term debt in financing its assets. This ratio is usually used as an indication to long term financial solvency of the company. It is a useful tool to determine the ability of the working capital structure to afford borrowing. The main difference between the TDTA and LTDTA is that the LTDTA doesn't count for short term debt as a source for capital financing according to the matching theory.

LTDTA can be calculated as follows:

$$
\text { Long Term Debt to Total Assets }=\frac{\text { Long Term Debt }}{\text { Total Assets }}
$$

\subsubsection{Total Debt to Equity (TDE)}

This ratio shows the relation between the outsider and shareholders' funds for the company's assets. It is often called Internal External Equities ratio. This ratio is used to show the amount of money that the company can borrow safely thus it gives an idea about the correctness of the long term financial policies of the company.

A high TDE ratio means that the company is extensively using debt in financing its growth, consequently, the earnings will be unstable as a result of the extra interest expenses. If the company uses a lot of debt to finance its operations, the interest expense of this debt may outweigh the return generated by this debt and becomes a problem to the company as it may lead to bankruptcy. This may seriously harm the shareholders.

TDE can be calculated as follows:

$$
\text { Total Debt to Equity }=\frac{\text { Total assets }- \text { Total Shareholder's Equity }}{\text { Total Shareholder's Equity }}
$$

\subsubsection{Long Term Debt to Equity (LTDE)}

This ratio shows the degree to which the company finances its assets through Owner's Funds compared to Creditor's Funds. As in LTDTA, this ratio doesn't count for short term debt as a source for capital financing. $L T D E$ ratio is an indication for the company's risk. When ratio increases the company's risk also increases and the company becomes more vulnerable to downturns in the economic cycle.

The $L T D E$ can be calculated as:

$$
\text { Long term Debt to Equity }=\frac{\text { Long Term Debt }}{\text { Total Shareholder's Equity }}
$$

\subsection{Control Variables}

On one hand, some specific characteristics of the companies and some macroeconomics factors can affect the degree to which the company is vulnerable to systematic risks. On the other hand, these specific characteristics and macroeconomics factors can minimize the random error in the proposed model in this study when used as control variables. For these reasons, four control variables will be used to denote the special characteristics of the 
company and the macroeconomics factors and to reduce the random error and thus to improve the explanatory power of the model $\left(\mathrm{R}^{2}\right)$ as follows:

\subsubsection{Profitability (PROF)}

Profitability affects the degree to which the company is affected by the market risk. According to (Schemer and Mathison, 1996, Gu and Kim, 2002, and Lee and Jang, 2007) there is an inverse relation between the uncertainty of the amount and the timing of the cash flows in one hand and the profitability of the company as a result of decreasing the probability of bankruptcy for the company in the other hand. Based on this the profitability variable as one of the control variables will be used in the proposed model. The basic earning power $(B E P)$ will also be used as a proxy for the profitability which can be calculated by dividing earnings before interest and taxes $(E B I T)$ by total assets as follows:

$$
\text { Basic Earning Power }=\frac{E B I T}{\text { Total Assets }}
$$

\subsubsection{Firm's Size (SIZE)}

The size of the firm has a significant negative effect on the systematic risks when $\beta$ is used to express the systematic risks when using the yearly returns of the firm, this is confirmed by (Handa et al., 1989, and Chan and Chen, 1988). Based on this, the size of the firm will be used as one of the control variables in this model. The SIZE as a proxy to the firm's size is defined as the natural logarithm of the firm's total assets, this is expressed as follows:

$$
S I Z E=\ln (\text { Total assets })
$$

\subsubsection{Operational Efficiency (EFF)}

Beccalli et al., (2006), studied the effect of the operational efficiency on the stock prices and thus the systematic risks. The study showed that the change in the operational efficiency can significantly explain the change in systematic risks. The assets turnover ratio is considered as one of the most important ratios that measure the operational efficiency. In this study Assets Turnover Ratio will be used as a proxy for the operational efficiency, which can be calculated by dividing sales by total assets as follows:

\subsubsection{Inflation (INF)}

$$
\text { Assets Turnover }=\frac{\text { Sales }}{\text { Total Assets }}
$$

The study of Khaldoun, (2011), showed that the macroeconomics factors have a positive effect on the systematic risks as they increase the probability that the company will be affected by the systematic risks. The model in this study will include the inflation factor $(I N F)$ as a control variable and it will be calculated by calculating the yearly change in consumer price index.

\section{Methodology}

This study is considered to be analytical and descriptive at the same time. The test for whether leverage always means risk was analytically performed and the general model used for the analysis had the following form:

$$
\beta_{i t}=\mathrm{f}\left(\text { LEV }_{\text {it }}, \text { Firm's Chracteristics }_{i t},{\text { Macroeconomic } \left.\text { factor }_{t}\right)}\right.
$$

In the analysis, the yearly observations of a total of 259 firms were implemented. The Systematic risk $(\beta)$ resulting from equation 2 is the dependent variable used in the model. As independent variables, four different definitions of leverage in addition to four control variables that have effect on the systematic risk namely were also used. The control variables are; Profitability $(B E P)$, firms size $(S I Z E)$, Operational Efficiency $(E F F)$, and Inflation $(I N F)$.

In the general model, the subscripts $i$ and $t$ refers to firm $i$ at time $t ; \beta$ is the proxy for the risk, LEV is the four alternative measures of the leverage: TDTA, LTDTA, TDE, and LTDE. Firm's characteristics are the vectors of three control variables incorporates; $P R O F$, SIZE, and EF, macroeconomic factor is the fourth control variable representing INF.

The general model suggests that the systematic risk $(\beta)$ of the firm $i$ at time $t$ is a function of its $L E V$, specific characteristics, and macroeconomic factors. So, the econometric model has been estimated by converting the general model as follows:

$$
\beta_{i t}=\alpha+\varphi_{n} L E V_{i t}+\gamma_{2} P_{R O F_{i t}}+\gamma_{3} S I Z E_{i t}+\gamma_{4} E F F_{i t}+\gamma_{5} I N F_{t}+\varepsilon_{i t}
$$


Where; $\beta_{i t}$, is the systematic risk measure for $i^{\text {th }}$ cross-sectional firm for the $t^{\text {th }}$ time period, with $i=1,2,3, \ldots, 30$, $t=1,2,3, \ldots, 11, \alpha$ is constant. $\varphi_{n}$ are unknown parameters of the $L E V$ variables to be estimated. PROF, SIZE, $E F F$, and $I N F$, are the control variables included in the model. $\gamma^{\prime} s$ unknown parameters of the firm's specific characteristics and the macroeconomic factor are included in the model to be estimated, and $\varepsilon$ is the error term.

According to the objectives of the study, the hypotheses to be tested are as follows:

$\mathrm{H}_{0}$ : Leverage has no significant effect on the systematic risk of the Jordanian industrial companies listed in ASE.

$\mathrm{H}_{1}$ : Leverage has a significant effect on the systematic risk of the Jordanian industrial companies listed in ASE.

The $\mathrm{H}_{0}$ will be rejected and $\mathrm{H}_{1}$ will be accepted if the SIG $\leq 0.05$, Otherwise, there is no sufficient reason to reject the $\mathrm{H}_{0}$ hypothesis.

\section{Results and Discussion}

The results of analyzing the effect of the leverage on risk using different measures of leverage are presented in the following section.

\subsection{Descriptive Analysis}

The mean, standard deviation, maximum and minimum of the variables are presented in Table 1. It shows that Jordanian industrial firms have, on average, a beta coefficient of 0.633 . This means that the sensitivity of returns for the Jordanian industrial companies for change in the market portfolio returns is low. Consequently, its systematic risk in general is lower than the systematic risk of the market portfolio.

Table 1. Descriptive Analysis of Variables

\begin{tabular}{l|lllll}
\hline Variable & $\mathrm{N}$ & Mean & Std. Dev & Minimum & Maximum \\
\hline Beta & 259 & 0.633 & 0.515 & -0.729 & 2.854 \\
TDTA & 259 & 0.2788 & 0.189 & 0.000 & 1.081 \\
LTDTA & 259 & 0.061 & 0.109 & 0.000 & 0.469 \\
TDE & 259 & 0.533 & 1.588 & 0.000 & 19.304 \\
LTDE & 259 & 0.139 & 0.609 & 0.000 & 8.246 \\
PROF & 259 & 0.029 & 0.09 & -0.586 & 0.514 \\
SIZE & 259 & 16.39 & 1.282 & 13.755 & 20.168 \\
EFF & 259 & 0.611 & 0.341 & 0.000 & 2.147 \\
INF & 259 & 4.542 & 4.095 & -0.700 & 13.900 \\
\hline Variables definitions are given at Appendix 1 \\
\hline
\end{tabular}

In addition, results show that on average, the leverage when scaled to total assets is $27.8 \%$ and $6.14 \%$ for $T D T A$ and LTDTA, respectively, while it is $53.32 \%$ and $13.94 \%$ for DTE and LDTE, respectively.

\subsection{Correlation Analysis}

Table 2 presents Pearson correlation coefficients matrix. Results show that Beta is significant with positive association with TDTA, LTDTA, TDE, and $L T D E$, revealing that, regardless of the definition used for leverage, the greater the level of the company's leverage the higher the level of the systematic risk Beta. 
Table 2. Pearson Correlation Coefficients

\begin{tabular}{|c|c|c|c|c|c|c|c|c|c|}
\hline & Beta & TDTA & LTDTA & TDE & LTDE & PROF & SIZE & EFF & INF \\
\hline Beta & 1 & & & & & & & & \\
\hline \multirow[t]{2}{*}{ TDTA } & $.236^{* *}$ & 1 & & & & & & & \\
\hline & .000 & & & & & & & & \\
\hline \multirow[t]{2}{*}{ LTDTA } & $.310^{* *}$ & $.671^{* *}$ & 1 & & & & & & \\
\hline & .000 & .000 & & & & & & & \\
\hline \multirow[t]{2}{*}{ TDE } & $.162^{* *}$ & $.353^{* *}$ & $.261^{* *}$ & 1 & & & & & \\
\hline & .009 & .000 & .000 & & & & & & \\
\hline \multirow[t]{2}{*}{ LTDE } & $.213^{* *}$ & $.340^{* *}$ & $.482^{* *}$ & $.912^{* *}$ & 1 & & & & \\
\hline & .001 & .000 & .000 & .000 & & & & & \\
\hline \multirow[t]{2}{*}{ PROF } & $.133^{*}$ & $-.139^{*}$ & -.041 & .060 & .057 & 1 & & & \\
\hline & .032 & .025 & .507 & .339 & .365 & & & & \\
\hline \multirow[t]{2}{*}{ SIZE } & $.403^{* *}$ & $.312^{* *}$ & $.406^{* *}$ & $.224^{* *}$ & $.268^{* *}$ & $.391^{* *}$ & 1 & & \\
\hline & .000 & .000 & .000 & .000 & .000 & .000 & & & \\
\hline \multirow[t]{2}{*}{ EFF } & $.186^{* *}$ & $.128^{*}$ & $-.167^{* *}$ & -.070 & $-.160^{* *}$ & $.226^{* *}$ & .082 & 1 & \\
\hline & .003 & .040 & .007 & .264 & .010 & .000 & .186 & & \\
\hline \multirow[t]{2}{*}{ INF } & -.126 & .043 & -.039 & .089 & .012 & .062 & .021 & .116 & 1 \\
\hline & .444 & .489 & .539 & .155 & .848 & .317 & .739 & .063 & \\
\hline
\end{tabular}

Variables definitions are given at Appendix 1; *,**; correlation is significant at 0.05, 0.01 respectively. Second line Sig. (2-taild)

Results presented in Table 2 also show that Beta is significant with positive association with PROF, this indicates that high profit firms are on average associated with high risk. This is consistent with the point of view that the higher the profit potential the higher the levels of risk.

Table 2 also illustrates that Beta is significant with positive correlation with SIZE, this means that large companies are more exposed to systemic risk than small ones. Another finding is that Beta has a positive correlation $E F F$, which means that the operational efficiency has a proportional relationship with the systematic risk. One reason for this result can be explained by understanding that firms with high operational efficiency tend to have high marginal sales which contributes significantly to the Company's EBIT. This confirms with high variability in EBIT leads to high systematic risk.

\subsection{Regression Analysis}

Results for the regression estimations in models 1 to 4 using Beta as the dependent variable are presented in Table 3, Each one of the four models tests the impact of a different definition of the leverage on the systematic risk twice. The first test is conducted without control variables, while and the second one is conducted with control variables.

The adjusted R-squares values with and without the control variables were compared for the four models. Comparison clarified that including the control variables improves the explanatory power of the models relative to the case were the control variables are absent, Therefore, the focus will be on the model's results that contains the control variables in the regression analysis. Results being not significantly different from zero will not be reported. 
Table 3. Regression Analysis of the Impact of Leverage on Systematic Risk

\begin{tabular}{|c|c|c|c|c|c|c|c|c|}
\hline & $\begin{array}{l}\text { Model } \\
1 \\
\end{array}$ & & $\begin{array}{l}\text { Model } \\
2 \\
\end{array}$ & & $\begin{array}{l}\text { Model } \\
3 \\
\end{array}$ & & $\begin{array}{l}\text { Model } \\
4 \\
\end{array}$ & \\
\hline Constant & .454 & -2.024 & .544 & -1.64 & .605 & -2.092 & .608 & -1.986 \\
\hline TDTA & $\begin{array}{l}.644^{* * *} \\
.000\end{array}$ & $\begin{array}{l}.257^{* * *} \\
.005\end{array}$ & - & - & - & - & - & - \\
\hline LTDTA & - & - & $\begin{array}{l}1.458^{* * *} \\
.002\end{array}$ & $\begin{array}{l}.987^{* * *} \\
.001\end{array}$ & - & - & - & - \\
\hline TDE & - & - & - & - & $\begin{array}{l}.053^{* * *} \\
.009\end{array}$ & $\begin{array}{l}.035^{* *} \\
.034\end{array}$ & - & - \\
\hline LTDE & - & - & - & - & - & - & $\begin{array}{l}.180^{* * *} \\
.001\end{array}$ & $\begin{array}{l}.129^{* * *} \\
.009\end{array}$ \\
\hline PROF & - & $\begin{array}{l}-.272 \\
.424\end{array}$ & - & $\begin{array}{l}-.221 \\
.494\end{array}$ & - & $\begin{array}{l}-.441 \\
.169\end{array}$ & - & $\begin{array}{l}-.433 \\
.175\end{array}$ \\
\hline SIZE & - & $\begin{array}{l}.154^{* * *} \\
.000\end{array}$ & - & $\begin{array}{l}.128^{* * *} \\
.000\end{array}$ & - & $\begin{array}{l}.161^{* *} \\
.023\end{array}$ & - & $\begin{array}{l}.153^{*} \\
.097\end{array}$ \\
\hline EFF & - & $\begin{array}{l}.261^{* * *} \\
.003\end{array}$ & - & $\begin{array}{l}.335^{* * *} \\
.000\end{array}$ & - & $\begin{array}{l}.301^{* *} \\
.035\end{array}$ & - & $\begin{array}{l}.327^{*} \\
.064\end{array}$ \\
\hline INF & - & $\begin{array}{l}-.020 \\
.512\end{array}$ & - & $\begin{array}{l}-.019 \\
.142\end{array}$ & - & $\begin{array}{l}-.022 \\
.301\end{array}$ & - & $\begin{array}{l}-.021 \\
.315\end{array}$ \\
\hline Adj. R-Square & .052 & .207 & .093 & .234 & .022 & .210 & .041 & .221 \\
\hline df. Regression & 1 & 5 & 1 & 5 & 1 & 5 & 1 & 5 \\
\hline Residual & 257 & 253 & 257 & 253 & 257 & 253 & 257 & 253 \\
\hline Total & 258 & 258 & 258 & 258 & 258 & 258 & 258 & 258 \\
\hline F. & 15.226 & 14.448 & 27.371 & 16.740 & 6.917 & 14.741 & 12.162 & 15.603 \\
\hline Sig. & .000 & .000 & .002 & .000 & .009 & .000 & .001 & .000 \\
\hline
\end{tabular}

In model 1, were leverage is defined as the total debt to total assets ratio, the TDTA affects the risk statistically significantly at a significant level less than 0.01 . Regression analysis showed that the TDTA, taking into account the special characteristics of the company and macroeconomic factors, is able to explain about $21 \%$ of the change in the level of the systematic risk.

Model 2 excludes short-term debt from total debt and defines the leverage as the ratio of long-term debt to total assets. This Model has been found to be statistically significantly associated with the systematic risk. LTDTA along with the special characteristics of the company and macroeconomic factors explain about $23 \%$ of the change in the systemic risk.

As for models 3 and 4, the regression analysis in Table 3 showed that when leverage ratios scaled by equity (e.g. TDE and LTDE) instead of total assets (e.g. TDTA and LTDTA), results have not changed, and leverage has remained significantly associated with systemic risks.

Another important result observed from the results in Table 3 is that all leverage definitions that have been used in the study (i.e. TDTA, LTDTA, TDE, and LTDE) are associated statistically significantly with systemic risk in the same direction, i.e., they have been associated with systemic risks with a direct relationship and are significantly different from zero.

\section{Conclusion}

The aim of this study is to explore whether leverage always means risk, using beta coefficient $(\beta)$ as proxy for the systematic risk, and four different definitions of the leverage. The result shows that for the Jordanian industrial firms, the leverage is a definite factor in estimating risk regardless of the method used in estimating leverage; the results also conclude that the leverage can explain $21 \%-24 \%$ of the variability in the systematic risk depending on the leverage ratio. Accordingly, the leverage from the Jordanian industrial firm's point of view always means risk, with the need to remember that risk is not necessarily a bad thing, since high profit potential often comes with high level of risk. 
This result is consistent with the traditional theory of capital structure, where greater level of debt in the capital structure comes along with greater risk.

\section{References}

Beaver, W., Kettler, P., \& Scholes M. (1970). The association between market determined and accounting determined risk measures. Accounting Review, 654-682.

Beccalli, E., Casu, B., \& Girardone, C. (2006). Efficiency and Stock Performance in European Banking. Journal of Business Finance \& Accounting, 33, 245-262. http://dx.doi.org/10.1111/j.1468-5957.2006.01362.x

Chan, K. C., \& Chen. (1988). An Unconditional Assets-Pricing Test and the Role of Firm Size as an Instrumental Variable for Risk. Journal of finance, 309-325. http://dx.doi.org/10.1111/j.1540-6261.1988.tb03941.x

Gu, Z., \& Kim, H. (2002). Determinants of restaurant systematic risk: a re-examination. Journal of Hospitality Financial Management, 10 (I), 1-14.

Hamada, R. S. (1972). The effect of the firm's capital structure on the systematic risk of common stock. Journal of Finance, 27, 435-452. http://dx.doi.org/10.1111/j.1540-6261.1972.tb00971.x

Handa, P., Kothari, S. P., \& Wasley, C. (1989). The Relationship Between the Return Interval and Betas: Implication for the Size Effect. Journal of Financial Economics, 79-100. http://dx.doi.org/10.1016/0304-405X(89)90006-8

Hong, G., \& Sarkar, S. (2007). Equity Systematic Risk (Beta) and Its Determinants. Contemporary Accounting Research, 24(2), 423-66. http://dx.doi.org/10.1506/8187-56KM-6511-Q532

Khaldoun M. Al-Qaisi. (2011). The Economic Determinants of Systematic Risk in the Jordanian Capital Market. International Journal of Business and Social Science, 2(20).

Kheder Alaghi. (2012). Operating leverage and systematic risk. African Journal of Business Management, 6(3), 1095-1099.

Kim, H., Gu, Z., \& Mattila, A. S. (2002). Hotel real estate investment trusts' risk features and beta determinants. Journal of Hospitality $\&$ Tourism Research, 26(2), 138-154. http://dx.doi.org/10.1177/1096348002026002004

Lee, J. S., \& Jang, S. C. S. (2007). The systematic-risk determinants of the US airline industry. Tourism Management, 28, 434-442. http://dx.doi.org/10.1016/j.tourman.2006.03.012

Mnzava, D. I. (et). (2009). The Significance of corporation Tax as a Determinants of Systematic Risk: Evidence using United Kingdom(UK) Data. KCA Journal of Business Management, 2(1).

Robert G. Bowman. (1979). The Theoretical Relationship Between Systematic Risk and Financial (Accounting) Variables. The Journal of Finance, 34(3), 617-630. http://dx.doi.org/10.1111/j.1540-6261.1979.tb02129.x.

Ross, S. A., Westerfield, R. W., \& Jaffe, J. (2001). Corporate Finance, sixth ed. McGraw-Hill.

Schemer, P. S., \& Mathison, T. J. (1996). Investment strategies for REIT investors. Real Estate Review, 26(I), 5-10.

Shefrin, H., \& Statman, M. (2000). Behavioral Portfolio Theory. Journal of Financial and Quantitative Analysis, 35(2), 127-151. http://dx.doi.org/10.2307/2676187 


\section{Appendix 1. Notation and measure of the variable used in the study}

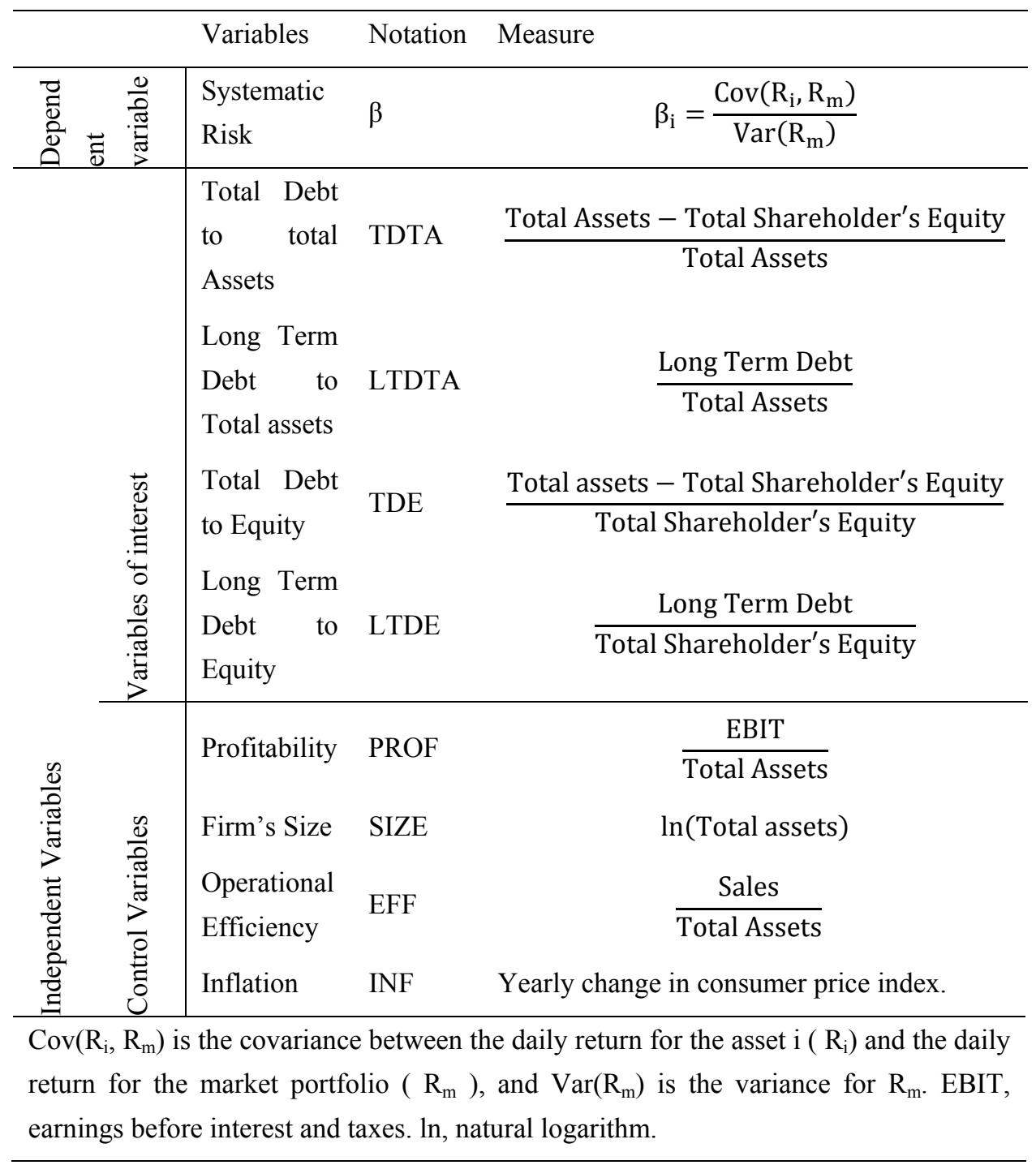

